\title{
Green Marketing for Creating Awareness for Green Consumerism
}

\section{Mohammad Yunus ${ }^{1}$, Mohammad Toufiqur Rahman ${ }^{2}$}

${ }^{1}$ Associate Professor, Dept. of Business Administration, International Islamic University Chittagong, BANGLADESH

${ }^{2}$ Asistant Professor, Dept. of Business Administration, International Islamic University Chittagong, BANGLADESH

\begin{abstract}
Green businesses are enterprises which consider environmental protection as an essential component for their long-term business objectives, both by promoting eco-efficient production activities and by marketing sustainable products and services (Barnes, n.d.). Green products may be defined as products or services that have a lesser or reduced bad effect on human health and the environment when compared with competing products or services that serve the same purpose (Website). The purposed of green business are (i) to promote more socially inclusive development (ii) to reduce environmental degradation (iii) to mitigate the effects of climate change (iv) to deal with pressures of population growth (v) to manage, issues of increased scarcity and volatile prices of raw materials effectively. Examples of green product are compact fluorescent lamps (CFLs), which use $75 \%$ less energy than ordinary incandescent ones, organic foods, which are grown and processed without antibiotics, pesticides, or synthetic fertilizers, hybrid electric vehicles such as the Toyota Prius, which achieves a fuel economy of 48 city-mpg and 45 highway-mpg (Website)., and green hotels, which are trying to conserve water, energy, and materials usage (Sharkey, 2008). Green business in practically existent everywhere around us. Company such as Wal-mart and General Electric transforming their business practices into green ones (Yeganeh \& Glavas, 2008). In a study conducted by MeKinsey of 4,238 business executives in 116 countries, $84 \%$ believed that business should contribute to the public good; however, only $3 \%$ believe that their companies are currently doing a good job (McKinsey, 2006). Thus, green business is an enterprise that has no negative impact on the (i) environment (ii) economy (iii) society (iv) community. Further, it meets the requirement of the triple bottom line such as financial benefits of the company, natural world betterment and social advantages for employees and members of the local community. The triple bottom line gives importance on initial value instead of the after effects.
\end{abstract}

Key words: Green Consumerism, Green products, Green business, volatile prices, triple bottom line.

JEL Classification Code: M31; Q13; P46 


\section{Criteria of Green Business}

The green business meets the following four criteria viz. (a) the business decisions of the company incorporate sustainability principles (b) the company manufactures environmentally friendly products/ services (c) it replaces demand for non-green products (d) it ensures enduring commitment to implement environmental principles in all business operations management (e) the company is totally different in concept as well as in practice. Thus, it is a business that "meets the needs of the present world without compromising the ability of the future generations to meet their own needs. The green business with the supply chain try to trade-off among the tree components of the triple bottom line concepts such as better impact on the environment, high growth of business and social development. As such, it argued that green business is a three legged stool of (i) people (ii) planet. However, the time line of key events in green product consumerism from 1998 to 2010 has been show in Fig.1.

\begin{tabular}{|l|l|}
\hline 1980 & $\begin{array}{l}\text { Few. Products carry environmental marketing messages. } \\
\text { But "organic" and "natural" foods gain popularity } \\
\text { Consumer awareness is heightened and more "green" choices arise : } \\
\text { homemade cleaning products and resource lists for shopping are } \\
\text { examples. } \\
\text { "Green" becomes a talk of the town only in the market but also in } \\
\text { academic. }\end{array}$ \\
\hline $\begin{array}{l}\text { Consumer willingness to pay for green features leads to a dramatic } \\
\text { increase in green consumerism. } \\
\text { 92\% European multinational companies rework product development } \\
\text { to reflect "green" concern; } 85 \% \text { alter production systems. } \\
\text { "Green" brands are niche markets. High levels of consumer concern are } \\
\text { not reflected in purchasing power. } \\
\text { Market shifts towards global business and affordable energy leading to } \\
\text { less spending on "green" products. }\end{array}$ \\
$\begin{array}{l}\text { Green building rating systems, eco labels and certification programs } \\
\text { increase in number. These programs largely focus on reduction of } \\
\text { greenhouse gas emissions, conservation and wise use of natural } \\
\text { resources and building occupant productivity related to IEQ. }\end{array}$ \\
$\begin{array}{l}\text { Research determines that protecting individual and family health is the } \\
\text { \#1 motivator for consumers to actively work towards protecting the } \\
\text { environment. Chemical emissions and exposure to very small traces of } \\
\text { VOCs from common indoor materials and finishes are found to impact } \\
\text { human health. } \\
\text { Total number of green products in stores increase by an average of } 79 \% \text {. } \\
\text { Studies show that } 60 \% \text { of those surveyed look for minimally packaged } \\
\text { goods, 58\% purchase green cleaning products and 31\% buy green } \\
\text { personal care products. }\end{array}$ \\
\hline $\begin{array}{l}\text { Green chemistry emerges and the federal government activity considers } \\
\text { integrating into legislation. }\end{array}$ \\
\hline 2010
\end{tabular}

[Source: Air Quality Sciences, Inc. (2010), p.2] 


\section{Green Products}

Green business produces green products. The green business should consider the strategies like water conservation, energy conversation, solid waste reduction and recycling, pollution, prevention, etc. Data, thus, collected regarding green products in study areas have been shown in the pie chart- 1 . The pie chart- 1 shows that $27 \%$ respondents were sapling plantation; $17 \%$ poultry farming; $15 \%$ fruits production; $11 \%$ manufacturing garments; $8 \%$ goat rearing; $7 \%$ rice production; $5 \%$ dairy farming; $6 \%$ flower production and $4 \%$ furniture manufacturing.

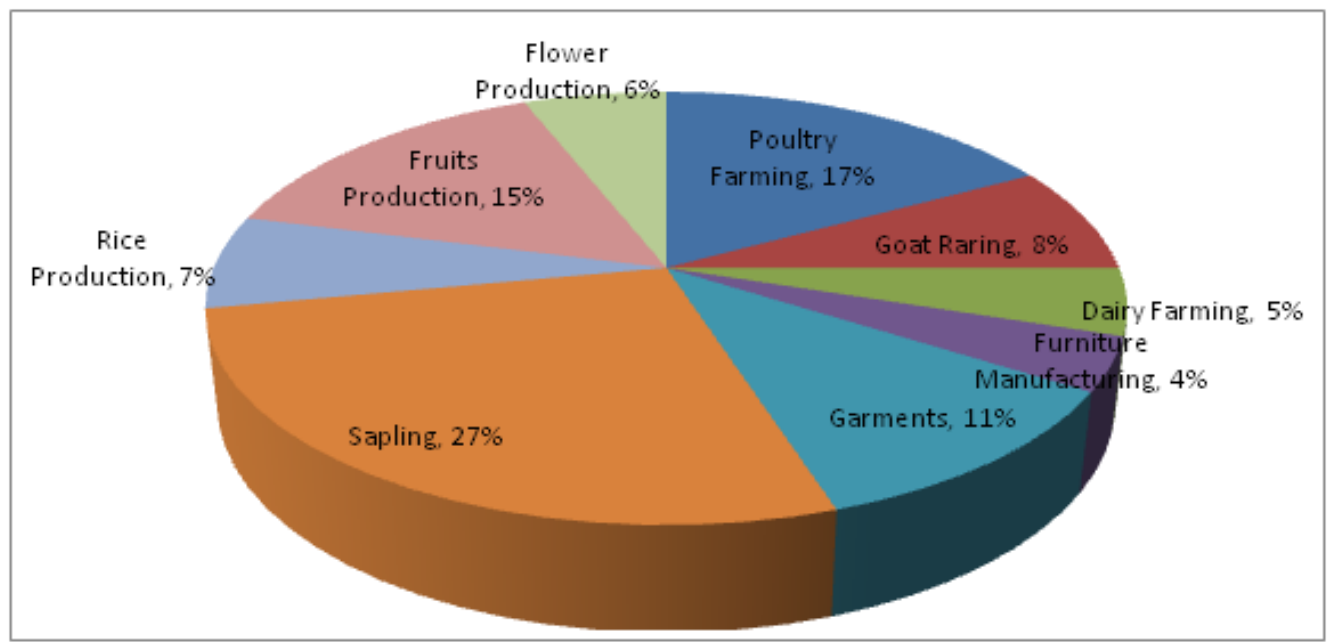

Figure- 1: Pie Chart-Green Products

It has been reported that the respondents are motivated to work hard for their livelihoods. The research identified that there are two types of capital required to change the pattern of growth of the study areas viz. human capital and social capital. Human capital may be defined as the capabilities of an individual or group i.e. the knowledge, training and skills that contribute to increase their productivity in their production system. Social capital may be defined as the connections among different stake-holders within social networks that have a value for their mutual benefits. It has been reported that the sample respondents of the study areas are in the following vicious cycle in figure-2:

\section{Poverty}
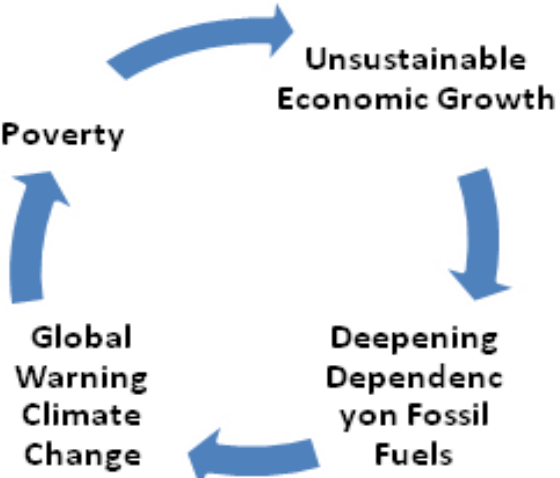

Deepening

Dependenc yon Fossil

Fuels

Figure-2: Vicious Cycle 


\section{Green Consumer}

Green consumers are the consumers who choose to purchase environmentally friendly products. The development of green products whether in the context $f$ human resources, operations or marketing required new ideas while dealing with added constrained of environmental and consumer pressures (Cronin, et. al., 2010). However, the activities of green products are as follows (Amatruda, 2010):

- Incorporate recycle content

- $\quad$ Renewable resources

- $\quad$ Local resources and manufactures

- $\quad$ Employ sustainable harvesting practices wood or bio-based

- $\quad$ Bio degradable

- $\quad$ Easily reused either whole or through dissembling

- $\quad$ Be able to readily recycle without significant deterioration of quality

\section{Green JobS}

Green jobs may be defined as activities that contribute substantially to preserving environmental quality. These jobs are plumbers, electricians, general workers, environmental specialist, etc. The literature review reveals that the sectors of economy can create new green jobs. These sectors are sustainable agriculture, transportation, energy efficiency, renewable energy, etc. It has been reported that the livelihoods of he sample respondents may be changed through green business training. These are (i) to familiarize stakeholders with green business and related concepts (ii) to illustrate the importance/interrelations among of green businesses (iii) to identify possible policies and measure for implementation (iv) to make proactive corporate marketing and active government intervention, etc. The mechanism of government interventions are (a) regulations (b) to make reformation (c) re-consumption (d) reorientation (e) reorganization (Dutta, 2009).

Further, it has been revealed that the steps to green business are as (i) learning what it means to be a green business (ii) reduce consumption, waste and pollution (iii) re-use what ones have (iv) recycle everything ones can (v) learn low going green can save money (vi) green ones business from the ground up (vii) develop and implement a green checklist (viii) review ones processes (ix) environmental education \& networking, etc.

\section{Concluding Remarks}

Green consumerism includes mainly 3 ' $R$ ' like Reduce, Re-use and Recycle, Reduce consumption means turn-off lights, recyclable packaging, reduce car use, etc. Re-use means repurchase rechargeable batteries, washable towels, re-useable shopping bags, etc Recycle means re-blending, reprocessing, and recyclable products, recycle papers, etc. It has been observe that cans bottles, plastics, paper, cardboard can all be recycled easily. By analyzing existing literature and based on our field survey, it may be concluded that green businesses aswell as green jobs may be explored for better livelihoods of the sample respondents of study areas. As such, for creating fortune for the rural women especially for women the virtuous cycle may be considered which has been show in figure- 03 . 


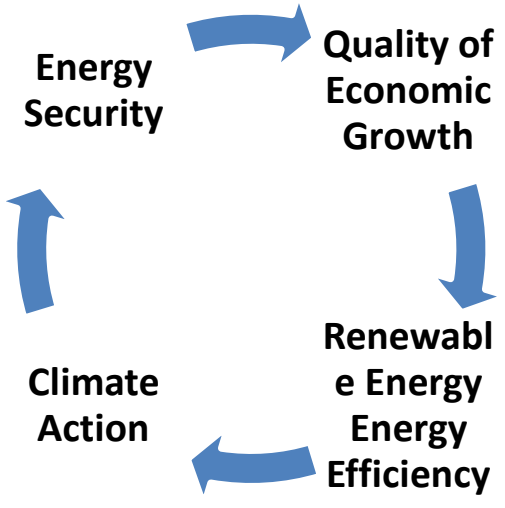

Figure-3: Virtuous Cycle

\section{REFERENCES}

Amatruda J. (2010), “Evaluation and Selecting Green products," Whole Building Design Guide Website. Natonal Institute of Building Sciences. July 23, 2010. Washington, DC.

Barnes, Ian (n.d), "Greening Business", Green Growth Capacity Development Program, ESCAP.

Cronin, J. Joseph et. al. (2010), "Green Marketing Strategies: An Examination of Stakeholders and the

Opportunities They Present," Academy of Marketing Science 2010.

Dutta, B (2009), "Sustainable Green Marketing" The new Imperative quoted in APJRBM Vol. 1 Issue 2, P.5.

http://www.energystar.gov

http://www.epa.gov.

http://www.ofee.gov/eo/13101.asp

http://www.toyota.com

J.Sharkey (2008), Hotels Struggle to Find the Right Eco-Message, The New Times, June 3,

McKinsey, (2006, January). The McKinsey global survey of business executives: Business and society

[Electronic version]. McKinsey Quarterly.

www.wbdg.org/resources/greenproducts.php.

Yeganeh, Bauback and Glavas, Ante (2008), OD Practitioner Vol. 40 No.2,P.8 
